\title{
E-government maturity models: more of the same?
}

\author{
Ilka Massue Sabino Kawashita \\ College of Business and Information \\ Technology \\ University of Phoenix \\ Phoenix, USA \\ ikawashi@gmail.com
}

\author{
Ana Alice Baptista \\ Information Systems Department \\ University of Minho \\ Guimarães, Portugal \\ ORCID: 0000-0003-3525-0619
}

\author{
Delfina Soares \\ Operating Unit on Policy-Driven \\ Electronic Governance (UNU-EGOV) \\ United Nations University \\ Guimarães, Portugal \\ ORCID: 0000-0002-2835-4789
}

\begin{abstract}
As e-government initiatives progressed, several models for measuring e-government maturity were proposed. Many are stage models based on the Capability Maturity Model (CMM) in which e-government maturity is conceptualized as stages of growth that evolve over time. The paper aims to investigate if e-government stage maturity models measure the use and usefulness of $e$ government._A meta-synthesis technique was used to compare and contrast 11 meta-models (models derived from other models), at the stage level, for their perspectives, concepts, metaphors, and their similarities and differences. We found that although models use different names and metaphors for analogous concepts, similarities exist among them, and individual stages overlap. Results show two gaps in research regarding the assessment of the actual use and usefulness of e-government. First, meta-models primarily assess the supply-side and operational/technology and citizen/service perspectives. Second, the use and usefulness of e-government are not addressed.
\end{abstract}

Keywords-E-government, e-services, maturity models, stage model, meta-model, e-government maturity assessment, qualitative meta-synthesis.

\section{INTRODUCTION}

Governments have been using Information and Communication Technologies (ICT) for decades. According to Norris [1], traditional Information Technology (IT) in government is inward-looking. It mainly addresses internal government applications such as payroll, accounting, and emergency lines. They aim to automate operations, gain efficiency, and ultimately offer better services to society. In contrast, e-government is outward-looking as the provision of information and services is primarily meant to external stakeholders. E-government connects government to citizens, businesses, its employees, and other instances of government. Despite the variety of motives for implementing egovernment, the principal motive is electronic access (online versus in person) by external parties to governmental information and services.

For the most part, this interaction has been through government portals on the World Wide Web [1]. Hence, egovernment maturity has been associated to the degree a government has established its presence on the Web [2]-[5]. Web presence relates to the publication of static and dynamic data on official web portals, access to databases, and a variety of online services. The sophistication of the services offered directly impacts the level of security and the complexity of the infrastructure required [6]. The increasing levels of complexity and sophistication are not built overnight. And egovernment maturity usually represents a continuum of developmental stages, from publishing information to supporting online transactions, with some governments having progressed further than others [7].

Thus, the use of stage maturity models to gauge egovernment maturity. However, traditional maturity models suppose well-controlled processes geared to continuous improvement. The last maturity level is known in advance, and the model is close ended. E-government stage maturity models are not close-ended. New stages are expected as Information and Communication Technologies (ICT) evolve at a fast pace, and the demands of society for new services arise.

Davis [8] developed and validated scales for measuring perceived usefulness and perceived ease of use to understand and influence unwilling users to accept and use computer systems. He found that these variables have a significant correlation with self-reported current usage and self-predicted future usage. Perceived usefulness refers to "the degree to which a person believes that using a particular system would enhance his or her job performance" [8]. In this context, the usefulness or utility of e-government means if it is helpful, beneficial, or serviceable to its intended users [9]. Use refers to the actual usage or utilization of e-government initiatives. This article intends to call the attention of researchers and practitioners to the gap that exists between factors that influence the adoption of e-government and maturity assessment tools such as stage maturity models. Perceived usefulness is a determinant factor of the intention and actual of use of e-government [10], [11]. In contribution, this article identifies and reviews e-government maturity models to determine whether and how e-government usefulness and use are addressed.

We conduct a tertiary study to review articles related to egovernment stage maturity models published between 1988 and 2019. We focus on meta-models, i.e., models derived from other models to reduce the number of studies surveyed and still acknowledge previous research done on the field. A qualitative meta-synthesis is adopted to compare and contrast 11 e-government maturity meta-models to understand, at the stage level, their perspectives, metaphors and concepts, and their similarities and differences. We seek evidence whether any of the stages address the impact, use, and usefulness of egovernment. Moreover, we survey the methods used to develop the models, year of their publication, and background influence.

This paper is organized as follows. Section II describes egovernment maturity models. While section III presents the research methodology. Section IV applies a qualitative metasynthesis to the selected maturity models and reports results. In section $\mathrm{V}$, we present discussions and the limitations of this work. In section VI, we draw our conclusions and suggest future work.

\section{E-GOVERnMent MATURITy MODELS}

This section describes capability maturity models and some of the first e-government maturity models published in the literature.

In Information Systems (IS), maturity is usually measured against "capabilities," so a Capability Maturity can be defined as capability measured against some desired state or goal. According to Mettler [12], in IS research, maturity models are 
understood as tools that can facilitate internal and/or external benchmarking, present possible improvements, and provide guidelines through the evolutionary process of organizational development and growth.

The Software Engineering Institute (SEI) states that Capability Maturity Models "(CMMs) focus on improving processes in an organization. They contain the essential elements of effective processes for one or more disciplines and describe an evolutionary improvement path from ad hoc, immature processes to disciplined, mature processes with improved quality and effectiveness." [13]. CMM provides a set of effective practices that addresses productivity, performance, costs, and stakeholder satisfaction for systematic and evolutionary process improvement. One of the most popular IS capability maturity models is the Capability Maturity Model Integration (CMMI) [14]. It is the successor of the Software Capability Maturity Model (Software CMM) [13]. Software CMM and CMMI were created for the development, maintenance, and acquisition of software products and services. However, other models from different areas [15] adopted their five-stage capability maturity level and the means for determining those levels [16], such as in egovernment. This study focuses on governmental stage maturity models as categorized by Concha et al. [17] and as in some of the models presented below.

The Layne and Lee [4] e-government maturity model is one of the most known and influential academic models, with 3038 citations reported on Google Scholar and 1431 on Scopus as of August 2019. Layne and Lee propose an evolutionary four-stage model based on observations of egovernment initiatives in the US. The Hiller and Belanger's [18] model was one of the first to appear in the academic literature that contemplates the political perspective. They proposed a five-stage maturity model for e-government. Moon [19] adopts the Hiller and Belanger's model with minor terminology differences to assess the evolution of egovernment in US municipalities. Gartner's [2] four-stage egovernment maturity model surveys the evolution of egovernment online interaction with customers. It also identifies a strategy and other factors that contribute to success in each phase. Accenture 2003 model is similar to the Gartner's with minor adjustments (change stage names, but not concepts) [6]. The United Nations and American Society for Public Administration 2001 [20], also known as the UN 2001, is a five-stage maturity model. The United Nations (UN) model has evolved over the years; it added eparticipation to its stages in the 2003 to 2008 surveys. Davison et al. [21] proposed a five-stage alignment-based maturity model to explain three "typical transition paths" from government to e-government.

These models do not combine different e-government perspectives technology, organization, management, and politics, which are fragmented across metaphors and concepts [6], [22]. The UN 2001, Gartner, and Layne and Lee models do not contemplate the improvements of political development and democracy, which are some of the main egovernment goals. The UN 2001 model focus on the benefits of improving the front-office [23] (web-based services) and does not address the transformation of government operations to improve efficiency. Gartner's model focuses on the customer. However, it does not address the improvement of internal operations [24]. Lee [6] contends that the edemocracy stage that Siau and Long [24] added to their model does not represent an evolution of their model previous stages. They argue that e-democracy is not an evolution of transformation. As Heeks [25] states, all maturity models are a product of their time, context, and mindset. As such, the models discussed above are not yet concerned with the impact, use, or usefulness of e-government initiatives. Their focus is on the supply of e-government, i.e., the implementation of Information and Communication Technologies to improve the efficiency of government services provided online.

\section{MEthodology}

Meta-synthesis is a technique that attempts to integrate results from many different but inter-related qualitative studies. It intends to be interpretive, rather than deductive. In contrast to a meta-analysis of quantitative studies, which aims to increase certainty in cause and effect conclusions. Differently, qualitative meta-synthesis seeks to understand and explain phenomena [23]. Qualitative meta-synthesis is an exploratory research method designed to build or extract a common frame of reference from qualitative research results [6]. Stage models are mostly developed qualitatively [15]; thus, a qualitative meta-synthesis technique was selected as the research method for this study. We selected Wash and Downe's [23] seven-step technique for conducting this study's qualitative meta-synthesis. The last three steps of the technique are based on Noblit and Hare [26]. Table I presents a summary of these steps and their descriptions.

TABLE I. META-SYNTHESIS TECHNIQUE. SOURCE: WASH AND DOWNE [23]

\begin{tabular}{|c|c|}
\hline $\begin{array}{l}\text { Meta-Synthesis } \\
\text { Steps }\end{array}$ & Description \\
\hline $\begin{array}{l}\text { Framing a meta- } \\
\text { synthesis exercise }\end{array}$ & $\begin{array}{l}\text { Appropriate research question, purpose or aim frames } \\
\text { a meta-synthesis. }\end{array}$ \\
\hline $\begin{array}{l}\text { Locating relevant } \\
\text { papers }\end{array}$ & $\begin{array}{l}\text { Undertake a robust search of on the topic area being } \\
\text { studied. Acknowledgement of the potential that search } \\
\text { directions may be divergent, rather than linear in } \\
\text { meta-synthesis. }\end{array}$ \\
\hline $\begin{array}{l}\text { Deciding what to } \\
\text { include }\end{array}$ & $\begin{array}{l}\text { Identify and compare methods, validity and scope of } \\
\text { each study and decide the scope of the meta-synthesis. }\end{array}$ \\
\hline $\begin{array}{l}\text { Appraisal of } \\
\text { studies }\end{array}$ & $\begin{array}{l}\text { Identify and apply predefined criteria used to appraise } \\
\text { the rigor of studies. }\end{array}$ \\
\hline $\begin{array}{l}\text { Compare and } \\
\text { contrast exercise }\end{array}$ & $\begin{array}{l}\text { Noblit and Hare [26] understanding of key metaphors, } \\
\text { phrases, ideas, concepts, and relations in each study is } \\
\text { identified, and usually tabulated. These findings are } \\
\text { then juxtaposed to both identify homogeneity of } \\
\text { categories/codes/themes and, crucially, to note } \\
\text { discordance and dissonance. }\end{array}$ \\
\hline $\begin{array}{l}\text { Reciprocal } \\
\text { translation }\end{array}$ & $\begin{array}{l}\text { The translation of one study's findings into another, } \\
\text { using metaphors and concepts that could be applied to } \\
\text { both. 'Refutational translation' and overlap may } \\
\text { contribute to another, emergent, category or } \\
\text { understanding which has not been identified in the } \\
\text { original accounts. }\end{array}$ \\
\hline $\begin{array}{l}\text { Synthesis of } \\
\text { translation }\end{array}$ & $\begin{array}{l}\text { Clusters of metaphors become refined and a } \\
\text { consensus emerges as to core themes, new concepts } \\
\text { and exploratory theories. The synthesis needs to } \\
\text { reflect the tension between contradictory or } \\
\text { alternative explanations if reciprocal translations } \\
\text { suggest a lack of congruence. }\end{array}$ \\
\hline
\end{tabular}

\section{Qualitative Meta-Synthesis Results}

\section{A. Framing the Meta-Synthesis Exercise}

The focus of his study is e-government stage maturity models to assess whether and how they address e-government use and usefulness. We investigate what are, at the stage level, their perspectives, metaphors and concepts, and their 
similarities and differences. We address the following questions. (1) What are the stages of e-government maturity models? (2) What are the characteristics (perspectives, metaphors, and concepts) of e-government maturity models? (3) What are the similarities and differences of e-government maturity models? (4) Do the stages of e-government maturity models measure the use or usefulness of e-government?

\section{B. Locating Relevant Papers}

We conducted a review of the literature based on peerreviewed articles published in academic conferences and journals on Scopus ${ }^{1}$ (148 results), Science Direct ${ }^{2}$ (164 results) and Web of Science ${ }^{3}$ (67 results) using the keywords "e-government" AND "maturity model" for the year > 1987. Instead of broadening our search with synonyms such as "e-gov" or "stage maturity level," we used a recursive search of a seeding article's citation tree and related work to find related studies. In the first screening process, all 379 articles were perused of keywords, titles, and abstracts to discard all non-relevant articles and duplicates. We only reviewed articles written in English after 1988. Among the remaining 187 articles, Siau and Long [24] was the first, we identified, that created an e-government maturity model using a metasynthesis technique. We conducted a recursive search of that article's citations and related works on Google Scholar to locate additional relevant literature and other maturity models. Supplementary sources include Google Scholar, ResearchGate, books and book chapters, international organizations and government articles, documents, reports, rankings, and benchmarks.

\section{Deciding What to Include}

Eleven articles, each proposing or adopting a stage maturity model resulting from a qualitative meta-synthesis or literature review, were selected. Our study draws from previous research. It conducts a tertiary-level qualitative metasynthesis of the e-government evolutive staged models (CMM based) as defined by Concha et al. [17]. These meta-models (models derived from other models) are the product of literature reviews or qualitative meta-synthesis proposed by individuals, consulting firms, international organizations, or governments. We did not include models created between 1999 and 2004, because most of them already accounted for in meta-models developed after 2005. The 11 e-government stage maturity models with their publication year, which includes Siau and Long 2005 [24]; Persson and Goldkuhl 2005 [27]; Shahkooh et al. 2008 [28]; Kim and Grant 2010 [29]; Lee 2010 [6]; Sandoval-Almazan and Gil-Garcia 2008 [30]; Fath-Allah et al. 2014 [31]; Almuftah et al. 2016 [32]; Janowski 2015 [33]; Nielsen 2016 [22]; and Iannacci et al. 2019 [34]. We briefly describe the models below.

Siau and Long [24] used a qualitative meta-synthesis approach to integrate five e-government stage models into a synthesized one. The surveyed models include Hiller and Belanger; Layne and Lee; Moon; the UN 2001; Gartner; and Deloitte and Touche. These models were created between 2000 and 2002. The authors proposed an e-government maturity model that has the following five stages: web presence, interaction, transaction, transformation (involves both vertical and horizontal), and e-democracy. The model keeps the names of Gartner's model and adds the fifth stage e- democracy from political participation of the Hiller and Belanger's model. The model does not address the use or usefulness of services provided.

Persson and Goldkuhl [27] surveyed and compared the Australian National Audit Office (ANAO 1999), the Swedish Agency for Administration Development (SAFAD 2000), Hiller and Belanger, and Layne and Lee and proposed a twostage maturity model. These models were published between 1999 and 2001. The authors claim that ANAO and SAFAD models are similar, both having four-stage levels: Information, Interaction, Transaction, and Integration. The firm Cap Gemini, on behalf of the European Union, used SAFAD for benchmarking the program eEurope 2002 with minor modifications (changed stage names and kept the stage descriptions) [35]. The Ernst \& Young 2003 model surveyed by Almuftah et al. corresponds to the European Union (EU) 2002. The stages of the Persson and Goldkuhl model are Integration in services, which incorporates all maturity levels presented in surveyed models. However, different agencies may render some services. The Integration in services represents the horizontal integration of services among government agencies plus takes into account the need to identify clients to offer services [27]. This model focuses on identifying who the user of the service in order to direct him to the correct Information System on the government web site. It does not matter if the service provided is useful or if it is used.

Sandoval-Almazan and Gil-Garcia [30] synthesized five theoretical models, including the UN 2001; Hiller and Belanger; Layne and Lee; Moon; and Holden et al. 2003 to propose a six-stage maturity model to assess local government portals in Mexico. The stages are Presence, Information, Interaction, Transaction, Integration, and Political. Surveyed models were developed between 2001 and 2003. The provision of services and the use of technology are the main focus of this model. It looks at the "target audience" of portals at the web design perspective. The use or usefulness of what is provided is not yet a concern.

Shahkooh et al. [36] reviewed and synthesized nine maturity models, which were published between 2000 and 2004. They included Deloitte and Touche; UN 2001; Layne and Lee; Accenture; Gartner; World Bank; Wescott; West; and Hiller and Belanger to create a five-stage maturity model. The e-government maturity stages identified are Online presence, interaction, transaction, transformation, and digital democracy. The authors posit that the complexity of technology and the number of e-government applications increase at a higher maturity level. The model is technologycentric and focuses on the supply of e-government and its enabling factors. The effective use of services or their helpfulness is not assessed.

Kim and Grant [29] proposed a five-stage maturity model after conducting a qualitative meta-synthesis of Capability Maturity Model Integration (CMMI) and six maturity models, published between 2000 and 2005, including Layne and Lee; UN 2001; Moon; Siau and Long; Andersen and Henriksen; and Hiller and Belanger. The framework is composed of four input areas (human capital, structural capital, relational capital, and IT investment) and five maturity stages (web

\footnotetext{
${ }^{1}$ https://www.scopus.com/

2 https://www.sciencedirect.com/
} 
presence, interaction, transaction, integration, and continuous improvement - a combination of transformation and egovernance stages of other models). These areas are assessed by using the Intellectual Capital (IC) management model and the Capability Maturity Model Integration (CMMI). The continuous improvement stage indicates that e-government is effectively achieved by continuously improving processes, the use of innovative technologies, and cooperation with other governments. It also implies that users participate in various political activities through web sites. It does not mention the usefulness of initiatives.

Lee [6] used a qualitative meta-synthesis to review and analyze 12 e-government stage models found in the literature between 2000 and 2009. The models are Hiller and Belanger; Layne and Lee; Scott; Netchaeva; West; Siau and Long; and Andersen and Henriksen; Center for Democracy \& Technology (World Bank); Accenture; United Nations 2001, 2003, 2005 and 2008; Gartner; and Deloitte Research. Lee proposed a frame of reference with five metaphors, which are presenting, assimilating, reforming, morphing, and egovernance. Each metaphor is broken into two underlying themes citizen/service and operation/technology. The citizen/service theme is further divided into five stages/concepts information, interaction, transaction, participation, and involvement. The operation/technology stages are integration, streamlining, transformation, and process management. The model is not concerned if egovernment initiatives are used or are useful.

Fath-Allah et al. [31] applied a qualitative meta-synthesis on 25 evolutionary stage e-government maturity models to identify their similarities and differences and also to find their weaknesses and strengths. Models were published between 2000 to 2012 . The study was later used to propose a best practice-based e-government portals maturity model [37]. This study drew on four other literature reviews Kim and Grant; Sandoval-Almazan and Gil-Garcia; Shahkooh et al.; and Siau and Long. The authors added other models to propose a four-stage model, including presence, interaction, transaction, and integration. The authors identified six important features (best practices) that an e-government maturity model should have. The features are one-stop-shop, customer centricity, interoperability, personalization, payment, and e-participation. The additional models surveyed are the United Nations 2012; Alhomod; Lee and Kwak; Chen; Cisco; Andersen and Henriksen; West; Reddick; World Bank; Accenture; Chandler and Emanuel; Windley; Moon; UK 2002, Netchaeva; Howard 2001; Layne and Lee; Wescott; Hiller and Belanger; Gartner; and Deloitte and Touche. FathAllah et al.'s model is geared towards the maturity of egovernment web portals. It does not assess the use or usefulness of e-government initiatives.

Janowski [33] proposed a four-stage evolutionary model to measure the maturity level of e-government strategies and initiatives: The Digital Government Evolution Model. Instead of a meta-synthesis, the author conducted an extensive literature review of digital government evolution to validate the model's characteristic variables. He surveyed 292 relevant research articles published in Government Information Quarterly between 1992 and 2014 to determine how their focus on Digital Government has evolved over the years. Each stage of the model represents a necessary step for the next stage. Stages are Digitization (Technology in government), Transformation (Electronic government), Engagement
(Electronic governance), Contextualization (Policy-driven electronic governance). Each phase is further characterized by three Boolean variables Internal government, Transformation affects external relationships, and Transformation is contextspecific [33]. The model focuses on civil participation and the efficiency of the organization. It does not focus on the use or usefulness of e-government.

Almuftah et al. [32] also conducted a qualitative metasynthesis to review 17 e-government stage models developed between 2001 and 2012. The proposed framework has three stages that capture Presence, Communication, and Integration. Two maturity variables were identified in all models: the level of complexity and the level of interaction. The level of complexity indicates that governments offer services that are more advanced and integrated at higher maturity levels. Moreover, the level of interaction between government and citizens increases at higher maturity levels. The models surveyed are Layne and Lee; Hiller and Belanger; Wescott; Kim and Grant; Chen; Alhomod; Lee and Kwak; UN 2001; Ernst and Young; World Bank; the UK National Audit (UKNAO) 2002; UN 2012 model; Price Water Cooper (PWC); Accenture; IBM; and CISCO. Like previous models, this model focuses on technology/ operations and service/citizen perspectives and does not address the impact, use, or usefulness of e-government.

Nielsen [22] surveyed 34 stage e-government maturity models to find gaps that could lead to future research on stage, cooperation, and governance models to help successfully develop e-services. He adopted Lee's [6] qualitative metasynthesis framework to compare and contrast models, which were created between 1999 to 2015. The models are Hiller and Belanger; Howard; Layne and Lee; Silcock; Wescott; Chandler and Emanuel; Moon; Netchaeva; Reddick; Waseda; West; Windley; Persson and Goldkuhl; Siau and Long; Andersen and Henriksen; Chan et al.; Shahkooh et al.; Sandoval-Almazan and Gil-Garcia; Kleivink and Janssen; Kim and Grant; Alhomod et al.; Lee and Kwak; Dias and Gomes; Heeks; United Nations (2001); European Union 2002; the World Bank; Gartner; Deloitte Research; Accenture; Cisco; ANAO 1999, SAFAD 2000, The United Kingdom National Audit Office (UKNAO) 2002. Nielsen discusses the outcomes and impact of e-government. However, as he adopts Lee's framework, the use or usefulness aspects are not addressed.

Iannacci et al. [34] compared ten models published between 2001 and 2015. The models are Layne and Lee; Andersen and Henriksen; West; Moon; Siau and Long; Gottschalk; Guijarro; Janowski; Davison et al., and Lee. Iannacci adopts Davison et al. [21] five-stage alignment-based maturity model. Innacci proposes the "turning point" theory and maturity model to explain the twists and turns of egovernment strategizing. The transition paths (stages) are Rhetorical intentions, Strategic planning, Systems development, Integration, and Transformation. The model was used to measure the maturity of the English system of criminal. Davison et al.'s model [21] focuses on the strategic alignment of e-government initiatives, and it does not deal with their use or usefulness.

Seven studies, Siau and Long 2005 [24]; Shahkooh et al. 2008 [28]; Kim and Grant 2010 [29]; Lee 2010 [6]; SandovalAlmazan and Gil-Garcia 2008 [30]; Fath-Allah et al. 2014 [31]; and Almuftah et al. 2016 [32], conducted qualitative meta-synthesis on existing maturity models and then provided 
their maturity models. While Nielsen 2016 [22] and Iannacci et al. 2019 [34] adopted existing frameworks to synthesize their findings, Persson and Goldkuhl 2005 [27] did a comparative study of four models. Janowski 2015 [33] surveyed 292 articles to validate the concepts underlying his model. Over 40 e-government maturity models were identified and considered in the creation of the 11 metamodels. The original maturity models have between two and twelve stages. They were developed between 1999 and 2015, being $73 \%$ of them created in the first ten years. Meta-models were published between 2005 and 2019. In terms of publication year, two models - Siau and Long, and Persson and Goldkuhl - were presented in 2005. Two models, Shahkooh et al.; and Sandoval-Almazan and Gil-Garcia, were published in 2008. Two models - Kim \& Grant and Lee - were published in 2010. Fath-Allah et al.'s model was presented in 2014. Janowski's model was published in 2015. Two models, Almuftah et al.; and Nielsen, were published in 2016. Moreover, one model, Iannacci et al. 2019, was published in 2019.

Layne and Lee and Hiller and Belanger models seem to be the most influential among the researchers as they appear in almost all studies; except in Janowski's. Moon follows close by being cited in eight studies. The Accenture model appears in six syntheses, while the Deloitte and Touche appears in five syntheses. The least influential models, built between 1999 and 2009, were Silcock; EU 2002; PWC; IBM; Waseda 2004; Davison et al.; Persson and Goldkuhl; Cisco; Chan et al.; and Klievink and Janssen, which were cited only once by other authors. Siau and Long meta-model [24] influenced five other meta-models. In contrast, the other meta-models were only cited once or twice.

\section{Appraising Studies}

All academic papers and articles were peer-reviewed and published in indexed conferences proceedings and journals. Governments and reputable international organizations produced surveys, reports, rankings, and benchmarks. Most methodologies are available online free of charge. For this study, the quality of the papers and their results have already been established.

\section{E. Comparing and Contrasting Maturity Meta-Models' Stages}

Stages were compared based on the level of the stage, its label, and description. Seven concepts (or stages) were distilled from the stages' labels and descriptions. Concepts are Presenting information, Interaction, Transaction, Integration, Transformation, e-Governance, and Policy-driven eGovernance. During the comparing and contrasting exercises, we did not identify concepts to assess the use or usefulness of e-government. For each model, the stage's name and description were compared and placed under the concept/stage it best suited. Models have between two and six stages. Persson and Goldkuhls has two; Almuftah et al. has three; Fath-Allah et al. and Janowski have four; SandovalAlmazan and Gil-Garcia model has six. The remaining six models have five stages. Persson and Goldkuhls' Integration in service and Janowski's Digitization first stages encompass the four first concepts identified in other models. Integration in service cover initiatives like publishing information on a web site to integrating government services at different levels, such as those of local governments and state governments. Digitization or Technology in Government includes egovernment initiatives such as the provision of a government portal and filing taxes online. Shahkooh et al.'s fourth stage, "Fully integrated/transformed e-government", encompasses the Integration and Transformation of most models. Next, we briefly describe each concept and summarize the comparing and contrasting exercises.

Stage 1 - It seems that publishing information on a public web site is one of the first e-government initiatives implemented. Although the differences in naming (web presence, online presence, rhetorical intentions). All models include the Presenting information stage. Persson and Goldkuhls' Integration in service and Janowski's Digitization stages encompass the concept of presenting the information. Sandoval-Almazan and Gil-Garcia's Presence (level 1) and Information (level 2) can be combined into this concept, as the levels are described as government providing information to the public. E-government initiatives can be classified based on the demand and/or on the supply of e-government. This stage assesses only the supply-side and is technology centric. The use or usefulness of web sites and data published is not addressed.

Stage 2 - This stage is about Interaction between government and users. It seems to follow the Presenting information stage. Despite the naming differences (interaction, assimilating, strategic planning) and of stage levels (Sandoval-Almazan and Gil-Garcia's Interaction is level 3), all models include this concept. At this stage, twoway communications are available (asking questions, pools). Iannacci et al.'s Strategic plan (start implementing web-based systems, services, or information sites), Lee's Assimilating; Persson and Goldkuhls' Integration in service and Janowski's Digitization stages incorporate the concept of interaction. Models are only concerned with the existence of the interaction; they do not address whether the interaction is useful or how many users interacted with the portal.

Stage 3 - For most models, stage 3 represents the ability to conduct transactions online. Sandoval-Almazan and GilGarcia's Transaction (level 4) and Persson and Goldkuhls' Integration in service require secure and identified transactions at this level. Lee's Reforming and Janowski's Digitization stages include the idea of conduct transactions. Some authors, Siau and Long; Sandoval-Almazan and GilGarcia; and Shahkooh et al. [24], [28], [30] mentioned the increase in the number of services provided, as well as the of the complexity of services. Iannacci et al.'s System development (potential for some integration between planning tasks or between planning and action) also covers the concept of a transaction. This stage focuses on the supply-side; it does not provide insights into who uses the services or if the interaction was useful.

Stage 4 - Integration seems to be the "natural" development path after the transaction stage. Layne and Lee were the first to use the terms vertical and horizontal Integration. Lee [6] clarifies "vertical integration refers to the system integration of similar functionality across different levels of government - local, state and central, while horizontal integration refers to the system integration among different functions of government.". These concepts were incorporated in all models, even if some models do not have a separate Integration stage. Siau and Long's Transformation stage covers integration, as well as Persson and Goldkuhls' Integration in service, Lee's Assimilating, and Janowski's Digitization stages. The focus of this stage is on the supplyside. It aims at increasing the efficiency of operations and 
technology; it does not look if service is being used or is useful.

Stage 5 - This stage deals with the Transformation of how services are rendered and the relationship between State and society. At this level, operational services are offered and improved for higher efficiency and user satisfaction as in Persson and Goldkuh; Janowski; Lee; and Kim and Grant. Some models Sandoval-Almazan and Gil-Garcia; Fath-Allah et al.; and Almuftah et al. do not present a separate Transformation stage, although they all include a separate Integration level. Lee [6] argues that models that focus on "integration" offer technology and operation-oriented perspective while models focused on "transformation" are geared towards the service and organization perspectives. This stage is the first to look into the demand-side, as user satisfaction is a dimension of service use and usefulness.

Stage 6 - The last stage represents social participation and e-Governance. Citizens can vote online and express political views through forums and boards. Despite not having a separated stage for e-governance/e-participation, some models, Persson and Goldkuhl; Kim and Grant; Fath-Allah et al.; Almuftah et al.; and Iannacci et al. did address these concepts in previous stages. Models that do not include a separate "e-governance" stage seem more focused on the technology/operation perspective, not so much in the citizen/service dimension. This stage focuses on the supplyside. Models are not concerned with the usefulness or outcomes of e-governance. Forums and boards are provided, but their use or impact is not measured.

Stage 7 - Janowski's model moves beyond the egovernance stage. The author proposes the Contextualization or the Policy-Driven Electronic Governance stage. It uses the technology and governance created by the Digital Government to "implement specific public policy and sustainable development goals in support of specific efforts by countries, cities, communities, and other territorial and social units to develop them." [33]. Services target specific users, such as low-income single-parent families, agricultural areas. This stage is concerned with the creation of public policies, not with their impact and outcomes. No other model addresses this concept.

\section{F. Reciprocating Translation}

Using a common frame of reference identified in Section E, we translate the models into one another. Seven concepts Presenting information, Interaction, Transaction, Integration, Transformation, e-Governance, and Policy-Driven EGovernance. In addition to the concepts, models are analyzed in two separate perspectives, the operational/technological and citizen/service.

\section{G. Synthesizing Translation}

Table II presents the translation of each of the 11 models into the meta-concepts/stages identified in Section E. When stage concepts match, the name of the stage appears on the column. Dark grey cells indicate that the concept does not exist in the model. Light grey columns show that the model's stage spans and encompasses several concepts.

All models provided for, Presenting information online, the first stage metaphor of e-government development. The initial stage "Information" relates both to the citizen/service and technology/operation perspectives. The interaction and transaction stages are more related to the citizen/service perspective. In contrast, integration and transformation are more related to the operation/technology perspective. This stage focuses on the supply-side and the operation and technology perspectives.

The Interaction stage metaphor exists in all surveyed models. It represents the replication online of processes and services offered in the real world. The concept of integration refers to the integration of interfaces, services, and data (both horizontal and vertical integration). Some models, Shahkooh et al.; Kim and Grant; Sandoval-Almazan and Gil-Garcia; and Iannacci et al. consider integration as high (four or above) maturity level, while others, Persson and Goldkuhl; Lee; Almuftah et al.; and Janowski, place the concept in lower levels. The concept of interaction, such as two-way communication, exists in all models - this stage is service and technology-oriented and concentrates on supplying egovernment.

The Transaction stage metaphor is about the restructuring of government business processes to take advantage of information systems and technologies, and the reformation of how governments conduct business with citizens. Siau and Long's model does not address the operation/technology dimension (streamlining) of the Reforming stage metaphor. However, all models contemplate the citizen/service dimension. At this stage, the political and administrative processes and services are reformed. The focus is on providing services online efficiently and improving internal operations. This stage is not concerned with the outcomes or impact or usefulness of the provided e-services.

At the Transformation stage metaphor, the political and administrative processes and services are reshaped for improved effectiveness. This stage refers to the changes in the shape and scope of processes. The government business model goes through a profound transformation, as the focus moves from the operationalization of services to planning and developing new services for citizens' benefit. In the citizen/service dimension, citizens can conduct more than simple transactions online. They can participate through surveys and pools actively. Transformation is an explicit concept in Siau and Long; Iannacci et al., and Janowski models. The concept also exists with different names in other models, Persson and Goldkuhl; Lee; and Nielsen. The concept of participation, although not explicit in most models, occurs in all of them. At this stage, there is a concern to provide/supply "benefits" through e-government.

The last stage metaphor of e-government development is e-Governance. In Lee's model, as the government starts its transformation into e-government, it uses the full capability of innovative information and communication technologies to reconfigure business processes of administrative and political services on the fly to support citizens' involvement in the government's decision-making processes. All models address the concept of involvement; however, the process management concept is only covered to a certain degree. The reconfiguration of processes in real-time was not found in any model. We consider the concept Contextualization or PolicyDriven E-Governance, identified in Section E, as part of the eGovernance metaphor. Thus, stages 6 and 7 merged. This stage is concerned with citizen involvement in politics and policymaking. E-government provides the means for involvement, but the use or usefulness of these initiatives are not assessed. 
TABLE II. COMPARISON OF THE STAGES OF 11 E-GOVERNMENT MATURITY MODELS

\begin{tabular}{|c|c|c|c|c|c|c|c|}
\hline $\begin{array}{l}\text { Underlying } \\
\text { concepts }\end{array}$ & $\begin{array}{l}\text { Presenting } \\
\text { Information }\end{array}$ & Interaction & Transaction & Integration & Transformation & e-Governance & $\begin{array}{l}\text { Policy Driven e- } \\
\text { governance }\end{array}$ \\
\hline $\begin{array}{c}\text { Stages / Model } \\
\text { Author }\end{array}$ & 1 & 2 & 3 & 4 & 5 & 6 & 7 \\
\hline Siau \& Long & Web presence & Interaction & Transaction & & Transformation & e-democracy & \\
\hline Persson \& Goldkuhl & \multicolumn{4}{|c|}{ Integration in services } & \multicolumn{2}{|c|}{ Integration of services } & \\
\hline Shahkooh et. Al. & Online presence & Interaction & Transaction & \multicolumn{2}{|c|}{$\begin{array}{l}\text { Fully integrated / transformed e- } \\
\text { government }\end{array}$} & Digital democracy & \\
\hline $\begin{array}{l}\text { Sandoval-Almazan } \\
\text { \& Gil-Garcia }\end{array}$ & Presence & Information & Interaction & Transaction & Integration & $\begin{array}{c}\text { Political } \\
\text { Participation }\end{array}$ & \\
\hline Kim \& Grant & Web presence & Interaction & Transaction & Integration & $\begin{array}{c}\text { Continuous } \\
\text { improvement }\end{array}$ & & \\
\hline Lee & Presenting & Assimilating & Reforming & & Morphing & e-Governace & \\
\hline Fath-Allah et al. & Presence & Interaction & Transaction & Integration & & & \\
\hline Janowski & \multicolumn{4}{|c|}{ Digitization } & Transformation & Engagement & Contextualization \\
\hline Almuftah et al. & Presence & Communication & Full Integration & & & & \\
\hline Nielsen & Presenting & Assimilating & Reforming & & Morphing & e-Governace & \\
\hline Iannacci & $\begin{array}{l}\text { Rhetorical } \\
\text { Intention }\end{array}$ & $\begin{array}{l}\text { Strategic } \\
\text { Planning }\end{array}$ & $\begin{array}{c}\text { Systems } \\
\text { Development }\end{array}$ & Integration & Transformation & & \\
\hline
\end{tabular}

\section{Discussion AND LiMITATIONS OF THIS WORK}

Eleven meta-models and their stages were compared and contrasted using a qualitative meta-synthesis. The name and description of the stages were used in a mapping exercise to identify underlying perspectives, metaphors, and concepts. Stages' similarities and differences were explored. The method used to create the model, the year of publication, and influence were also surveyed. Researchers [8]-[10] established that perceived usefulness is a determinant factor for the adoption of e-government. However, we did not identify any concept related to usefulness or actual use in any of the e-government maturity models surveyed. New stages could be added to the frame of reference to account for use and usefulness, and the provision of services not yet developed.

Qualitative meta-synthesis was the technique used to develop seven meta-models. Two models - Janowski, and Persson and Goldkuhl - did not derive their models from metasyntheses. Two studies did not propose new models Iannacci et al. surveyed early models and adopted Davison's framework [21]. While Nielsen conducted the meta-synthesis exercise using Lee's [6] frame of reference.

Meta-models were published between 2005 and 2019, and the majority is based on early models, especially on those developed between 1999 and 2003. Basic metaphors and concepts such as presenting information, transaction, and transformation were defined two decades ago and are still being used to measure the level of maturity of e-government initiatives. Several meta-models [6], [29], [31] are based not only on early models but also on other meta-models. Despite the apparent differences, metaphors, concepts, and perspectives extracted in most meta-models seem to be the same. This finding agrees with other authors [6], [22]. All meta-models are concerned with the operation/technology and services perspectives. They have several stages covering both perspectives and only one stage addressing e-governance and citizen participation. Their focus seems to be on the use of ICT as the means to achieve government reform and transformation. Meta-models measure the supply-side, i.e., the existence and level of sophistication of e-services offered on data portals. However, they do not measure the impact and outcomes of e-government initiatives, or the use or usefulness of e-services. Our findings align with other authors [22], [33].

Although the provision of e-government has evolved, none of the maturity models address actual use, as they are only technology and supply oriented [6], [38], [22]. This result deeply contrasts with public administration reform research, be it focused on the new public management efficiency or on the joined-up government approach (JUG) [39]-[43]. It also contrasts with the current view of international organizations in that the value-added of e-government can only be realized through the actual and effective use of provided services [44][46].

This study was limited by the number of meta-models surveyed and by the bias introduced by recursively searching citations for new models.

\section{CONCLUSIONS AND Future RESEARCH}

Qualitative meta-synthesis is a well-established technique among researchers for creating e-government stage maturity models. All surveyed meta-models address the e-governance and e-participation concepts that were lacking in some of the early models. E-government stage maturity models compare the state of e-government maturity in different countries at a certain point in time, thus fail to depict the evolution of egovernment. Despite the significant number of e-government stage maturity models identified in the literature, their underlying themes, metaphors, and concepts are similar. Models treat the technological, managerial, organizational, and political perspectives in a disjoint manner. The operation/technology perspective dominates the scene as the use of ICT is considered the enabler of e-government reform and transformation. These models do not address the actual use and usefulness of e-government.

Future research will investigate if other types of egovernment maturity models and benchmarks assess the impact, outcomes, use, and usefulness of e-government.

\section{REFERENCES}

[1] D. F. Norris, "E-Government 2020: Plus ça change, plus c'est la meme chose," Public Administration Review, vol. 70, no. s1, pp. s180 s181, 2010, doi: 10.1111/j.1540-6210.2010.02269.x. 
[2] C. Baum and A. Di Maio, "Gartner's Four Phases of EGovernment Model," Gartner, Nov-2000. [Online]. Available:

https://www.gartner.com/en/documents/317292/gartner-s-four-phases-of-egovernment-model. [Accessed: 23-Aug-2019].

[3] G. Cecconi and C. Radu, "Open Data Maturity in Europe 2018," European Data Portal, 4, Nov. 2018.

[4] K. Layne and J. Lee, "Developing fully functional Egovernment: A four stage model," Government Information Quarterly, vol. 18 , no. 2, pp. 122-136, Jun. 2001, doi: 10.1016/S0740-624X(01)00066-1. [5] United Nations, UN Global E-Government Survey 2003. UN, 2004 .

[6] J. Lee, "10year retrospect on stage models of e-Government: A qualitative meta-synthesis," Government Information Quarterly, vol. 27, no. 3, pp. 220-230, Jul. 2010, doi: 10.1016/j.giq.2009.12.009.

[7] D. M. West, "Global E-Government, 2007," 2007.

[8] F. D. Davis, "Perceived Usefulness, Perceived Ease of Use, and User Acceptance of Information Technology," MIS Quarterly, vol. 13, no. 3, pp. 319-340, 1989, doi: 10.2307/249008.

[9] S. S. Dawes, "Stewardship and usefulness: Policy principles for information-based transparency," Government Information Quarterly, vol. 27, no. 4, pp. 377-383, Oct. 2010, doi: 10.1016/j.giq.2010.07.001.

[10] J. D. Mahadeo, "Towards an Understanding of the Factors Influencing the Acceptance and Diffusion of e-Government Services," vol. 7, no. 4, p. 12, 2009.

[11] N. S. @ Ashaari, N. Z. Abidin, H. Kasimin, and S. H. M. Idris, "Malaysian e-Government application: Factors of actual use," Australian Journal of Basic and Applied Sciences, vol. 6, no. 12, pp. 325-334, Nov. 2012.

[12] T. Mettler, "Maturity assessment models: a design science research approach," International Journal of Society Systems Science, vol. 3, no. 1/2, p. 81, 2011, doi: 10.1504/IJSSS.2011.038934.

[13] SEI, "CMMI ${ }^{\circledR}$ for Development, Version 1.2," CMMI for Development, p. 573, 2006

[14] R. Wendler, "The maturity of maturity model research: A systematic mapping study," Information and Software Technology, vol. 54, no. 12, pp. 1317-1339, Dec. 2012, doi: 10.1016/j.infsof.2012.07.007. [15] D. Lee, J.-W. Gu, and H.-W. Jung, "Process maturity models: Classification by application sectors and validities studies," Journal of Software: Evolution and Process, 01-Apr-2019. [Online]. Available: https://onlinelibrary.wiley.com/doi/abs/10.1002/smr.2161. [Accessed: 20Aug-2019].

[16] G. Valdés, M. Solar, H. Astudillo, M. Iribarren, G. Concha, and M. Visconti, "Conception, development and implementation of an eGovernment maturity model in public agencies," Government Information Quarterly, vol. 28, no. 2, pp. 176-187, Apr. 2011, doi:

10.1016/j.giq.2010.04.007.

[17] G. Concha, H. Astudillo, M. Porrúa, and C. Pimenta, "EGovernment procurement observatory, maturity model and early measurements," Government Information Quarterly, vol. 29, pp. S43-S50, Jan. 2012, doi: 10.1016/j.giq.2011.08.005.

[18] J. S. Hiller and F. Bélanger, "Privacy Strategies for Electronic Government," in E-government 2001, Rowman \& Littkefieks Publishers INC, 2001.

[19] M. J. Moon, "The Evolution of E-Government among Municipalities: Rhetoric or Reality?," Public Administration Review, vol. 62, no. 4, pp. 424-433, Jan. 2002, doi: 10.1111/0033-3352.00196. [20] United Nations and American Society for Public Administration, Benchmarking E-government: A Global Perspective 2001. 2001.

[21] R. M. Davison, C. Wagner, and L. C. K. Ma, "From government to e-government: a transition model," Information Technology \& People, vol. 18, no. 3, pp. 280-299, Sep. 2005, doi: 10.1108/09593840510615888.

[22] M. M. Nielsen, "The Role of Governance, Cooperation, and eService Use in Current eGovernment Stage Models," in 2016 49th Hawaii International Conference on System Sciences (HICSS), Koloa, HI, USA, 2016, pp. 2850-2860, doi: 10.1109/HICSS.2016.357.

[23] D. Walsh and S. Downe, "Meta-synthesis method for qualitative research: a literature review," Journal of Advanced Nursing, vol. 50, no. 2 , pp. 204-211, 2005, doi: 10.1111/j.1365-2648.2005.03380.x.

[24] K. Siau and Y. Long, "Synthesizing e-government stage models - a meta-synthesis based on meta-ethnography approach," Industrial Management \& Data Systems, vol. 105, no. 4, pp. 443-458, May 2005, doi: $10.1108 / 02635570510592352$.

[25] R. Heeks, "A Better e-Government Maturity Model," iGovernment Briefing No. 9, 2015.
[26] G. W. Noblit and R. D. Hare, Meta-Ethnography: Synthesizing Qualitative Studies. SAGE, 1988.

[27] A. O. Persson and G. Goldkuhl, "Stage-models for public eservices - investigating conceptual foundations," 2005.

[28] K. A. Shahkooh, F. Saghafi, and A. Abdollahi, "A Proposed Model for E-government Maturity," in 2008 3rd International Conference on Information and Communication Technologies: From Theory to Applications, Damascus, Syria, 2008, pp. 1-5, doi:

10.1109/ICTTA.2008.4529948.

[29] D. Kim and G. Grant, "E-government maturity model using the capability maturity model integration," Journal of Systems and Information Technology, vol. 12, no. 3, pp. 230-244, Aug. 2010, doi:

$10.1108 / 13287261011070858$.

[30] R. S. Sandoval-Almazan and J. R. Gil-Garcia, "E-Government Portals in Mexico," in Electronic Government: Concepts, Methodologies, Tools, and Applications, IGI Global, 2008.

[31] A. Fath-Allah, L. Cheikhi, R. E. Al-Qutaish, and A. Idri, "EGOVERNMENT MATURITY MODELS: A COMPARATIVE STUDY," International Journal of Software Engineering, p. 22, 2014.

[32] H. Almuftah, V. Weerakkody, and U. Sivarajah, "Comparing and Contrasting e-Government Maturity Models: A Qualitative-Meta Synthesis," Innovation and the Public Sector, pp. 69-79, 2016, doi: 10.3233/978-1-61499-670-5-69.

[33] T. Janowski, "Digital government evolution: From transformation to contextualization," Government Information Quarterly, vol. 32, no. 3, pp. 221-236, Jul. 2015, doi: 10.1016/j.giq.2015.07.001. [34] F. Iannacci, A. P. Seepma, C. de Blok, and A. Resca, "Reappraising maturity models in e-Government research: The trajectoryturning point theory," The Journal of Strategic Information Systems, Feb. 2019, doi: 10.1016/j.jsis.2019.02.001.

[35] P. Cap Gemini Ernst \& Young, "Web-based Survey on Electronic Public services - Results of the Third Measurement," p. 53, Oct. 2002.

[36] K. A. Shahkooh, F. Saghafi, and A. Abdollahi, "A Proposed Model for E-government Maturity," in 2008 3rd International Conference on Information and Communication Technologies: From Theory to Applications, Damascus, Syria, 2008, pp. 1-5, doi:

10.1109/ICTTA.2008.4529948.

[37] A. Fath-Allah, L. Cheikhi, R. E. Al-Qutaish, and A. Idri, "Towards a Best Practice Based e-Government Portals Maturity Model," in International conference on Computer Science and Information Systems (ICSIS'2014) Oct 17-18, 2014 Dubai (UAE), 2014, doi:

10.15242/IIE.E1014034.

[38] S. M. Alhomod and M. M. Shafi, "Best Practices in E government: A review of Some Innovative Models Proposed in Different Countries," vol. 12, no. 01, p. 6, 2012

[39] F. Bannister, "Dismantling the silos: extracting new value from IT investments in public administration," Information Systems Journal, vol. 11, no. 1, pp. 65-84, 2001, doi: 10.1046/j.1365-2575.2001.00094.x.

[40] B. Klievink and M. Janssen, "Realizing joined-up government - Dynamic capabilities and stage models for transformation," Government Information Quarterly, vol. 26, no. 2, pp. 275-284, Apr. 2009, doi: 10.1016/j.giq.2008.12.007.

[41] A. Cordella and C. M. Bonina, "A public value perspective for ICT enabled public sector reforms: A theoretical reflection," Government Information Quarterly, vol. 29, no. 4, pp. 512-520, Oct. 2012, doi: $10.1016 /$ j.giq.2012.03.004.

[42] F. Bannister and R. Connolly, "ICT, public values and transformative government: A framework and programme for research," Government Information Quarterly, vol. 31, no. 1, pp. 119-128, Jan. 2014 doi: 10.1016/j.giq.2013.06.002.

[43] M. Meyerhoff Nielsen, "Governance Failure in Light of Government 3.0: Foundations for Building Next Generation eGovernment Maturity Models," in Government 3.0 - Next Generation Government Technology Infrastructure and Services: Roadmaps, Enabling Technologies \& Challenges, A. Ojo and J. Millard, Eds. Cham: Springer International Publishing, 2017, pp. 63-109.

[44] United Nations, Ed., E-government for the future we want. New York, 2014.

[45] G. Lafortune and B. Ubaldi, "OECD 2017 OURdata Index: Methodology and Results," OECD Working Papers on Public Governance 30, Dec. 2018

[46] D. Tinholt et al., "eGovernment Benchmark Insight Report 2019: Empowering Europeans through trusted digital public services," 2019 